\title{
Temperature, Leaf Wetness, and Isolate Effects on Infection of Minneola Tangelo Leaves by Alternaria sp.
}

Y. Canihos, Assistant Professor, Department of Plant Protection, University of Cukurova, Adana, Turkey; and T. L. Peever, Visiting Assistant in Plant Pathology, and L. W. Timmer, Professor, University of Florida, IFAS, Citrus Research and Education Center, 700 Experiment Station Road, Lake Alfred 33850

\begin{abstract}
Canihos, Y., Peever, T. L., and Timmer, L. W. 1999. Temperature, leaf wetness, and isolate effects on infection of Minneola tangelo leaves by Alternaria sp. Plant Dis. 83:429-433.

Alternaria brown spot causes necrotic lesions on immature leaves, twigs, and fruit of tangerines and their hybrids, reducing yield and fruit quality. The effect of temperature, leaf wetness, and isolate was evaluated in an in vitro system using immature detached leaves of Minneola tangelo. Infection was greatest at $27^{\circ} \mathrm{C}$, decreased gradually as the temperature declined to 24,20 , and $17^{\circ} \mathrm{C}$, and dropped sharply at $32^{\circ} \mathrm{C}$. Levels of infection were low at 4 and $8 \mathrm{~h}$ of leaf wetness and continued to increase with longer wetting periods up to $36 \mathrm{~h}$. A polynomial equation was developed that provided a good fit for the data (adjusted $R^{2}=0.93$ ). Isolates differed in aggressiveness, but there was no significant difference among isolates in their response to temperature and leaf wetness duration.
\end{abstract}

Alternaria brown spot is an important disease of tangerines (Citrus reticulata) and their hybrids. The causal agent was originally designated as Alternaria citri Ellis \& N. Pierce (9) and later renamed $A$. alternata (Fr.:Fr.) Keissl. pv. citri (12), but the proper classification of this pathogen remains in doubt (19). In addition to the tangerine pathogen, a genetically distinct strain or species attacks rough lemon and Rangpur lime. Both strains produce wellcharacterized host-specific toxins, each with a different mode of action (6). The tangerine cultivars affected in Florida include Murcotts, Dancy tangerines, and Minneola tangelos, as well as other hybrids of Dancy tangerines. The pathogen attacks immature leaves, twigs, and fruit, causing small necrotic lesions that may appear as early as $24 \mathrm{~h}$ after infection. Once the fungus is established and produces toxin, many leaves and fruit abscise, and twigs die back. The fungus also produces lesions on more mature fruit, ranging from small, necrotic spots to large, sunken pockmarks. Leaves become resistant when they mature, and fruit become resistant when they reach a diameter of about $3 \mathrm{~cm}$, usually

Corresponding author: L. W. Timmer

E-mail: 1wt@icon.lal.ufl.edu

Current address of second author: Department of Plant Pathology, Washington State University, P.O. Box 646430, Pullman 99164-6430.

Florida Agricultural Experiment Station Journal Series R-06474.

Accepted for publication 18 January 1999.

Publication no. D-1999-0222-01R

(C) 1999 The American Phytopathological Society late July in Florida. The disease was first described in Australia (9), first reported in Florida in 1976 (17), and also occurs in Colombia (2,3), Israel (13-15), South Africa (11), and Turkey (1).

Little is known about the epidemiology of Alternaria brown spot $(17,18)$. Sporulation occurs primarily on lesions on mature leaves (15), and free moisture or even high relative humidity (RH) brings about sporulation on such lesions (16). Spore release is triggered by abrupt changes in $\mathrm{RH}$ or by rainfall, but not by vibration or $\mathrm{red} /$ infrared irradiation. Infection of susceptible trap plants placed in the field weekly failed to reveal which environmental factors were essential for infection of leaves (16). In recent studies in Israel, the optimum temperature for lesion expansion was determined to be 20 to $25^{\circ} \mathrm{C}$ (14).

Alternaria brown spot is difficult to control, and frequent applications of iprodione or copper fungicides are used to prevent fruit drop and to produce blemishfree fruit for the fresh market. In Florida, applications are made on a 10- to 14-day schedule from late February to mid-July to achieve acceptable control in heavily infested orchards. In semiarid areas, such as Israel and South Africa, six to eight sprays are required $(11,13)$. In Colombia, where rainfall and temperatures are high, weekly sprays year-round were required to achieve control (3). In certain areas, production of Minneola tangelo and other susceptible cultivars has been largely abandoned due to this disease.

Currently, fungicide applications are based on a calendar schedule or on tree phenology. Predictive models that use duration of leaf wetness and temperatures required for infection have been useful in predicting disease and timing fungicide applications on similar diseases of tree crops $(4,7,10)$. Predictive models should be helpful for reducing the number of fungicide applications and for improving control of brown spot. In this study, we investigated the effect of temperature, leaf wetness duration, and isolates on the infection of detached leaves of Minneola tangelo with the goal of developing models useful in the field.

\section{MATERIALS AND METHODS}

Inoculum production, plant material, and inoculations. The $\mathrm{SH}-1$ isolate of Alternaria sp. was obtained from a Minneola tangelo grove near Polk City, Florida. Conidial inoculum was produced by growing the fungus on potato dextrose agar (Difco, Detroit, MI) for 3 to 5 days at $27^{\circ} \mathrm{C}$. The surface of the plates was scraped with a scalpel to remove aerial mycelium, and the colony was cut into approximately $4 \mathrm{~mm}^{2}$ pieces. About 50 to 100 pieces were then transferred to each plate of a sporulation medium consisting of $30 \mathrm{~g}$ of $\mathrm{CaCO}_{3}, 20 \mathrm{~g}$ of sucrose and $20 \mathrm{~g}$ of agar per liter of distilled water. Two milliliters of sterile distilled water was added to each plate, and the plates were sealed with Parafilm and incubated with $12 \mathrm{~h}$ per day of fluorescent light for 3 to 4 days at $27^{\circ} \mathrm{C}$. Conidia were collected by adding $10 \mathrm{ml}$ of sterile distilled water to each plate and gently brushing the colonies and then filtering the suspension through two layers of cheesecloth to remove mycelial fragments. Conidia were washed twice in sterile distilled water by centrifugation to remove additional mycelium and any toxin carried over from the culture plates. Conidial suspensions were adjusted to $10^{4}$ conidia per $\mathrm{ml}$ using a hemacytometer. Preliminary experiments using conidial concentrations of $10^{3}, 10^{4}, 10^{5}$, and $10^{6}$ conidia per $\mathrm{ml}$ revealed that $10^{4}$ conidia per $\mathrm{ml}$ gave a scorable number of lesions on each leaf.

Leaves for inoculation were produced from 1- to 2-year-old Minneola tangelo (Citrus reticulata Blanco $\times C$. paradisi Macf.) trees on rough lemon (C. jambhiri Lush) rootstock grown in the greenhouse. Succulent young leaves about $3 \mathrm{~cm}$ long were collected for inoculation. In the past, inoculations have generally been conducted by placing droplets or filter paper disks with conidia on detached leaves to evaluate cultivar susceptibility $(6,9,14)$. In 
Table 1. Analysis of variance of the effect of temperature and duration of leaf wetness on the number of lesions per leaf of Minneola tangelo inoculated with Alternaria sp. isolate SH-1

\begin{tabular}{|c|c|c|c|c|c|c|c|}
\hline Source & df & SS & MS & EMS & $F$ test & $\boldsymbol{F}$ & $\boldsymbol{P}$ \\
\hline Experiment & 3 & 9.72 & 1.59 & MSA & MSA/MSE & 8.8 & $<0.0001$ \\
\hline Temp & 4 & 42.11 & 11.36 & MSB & MSB/MSE & 62.9 & $<0.0001$ \\
\hline Time & 4 & 86.97 & 21.00 & MSC & MSC/MSE & 116.2 & $<0.0001$ \\
\hline Temp*time & 16 & 14.45 & 0.90 & MSBC & MSBC/MSE & 5.0 & $<0.0001$ \\
\hline Error & 54 & 9.75 & 0.18 & MSE & & & \\
\hline Total & 81 & 163.01 & & & & & \\
\hline
\end{tabular}

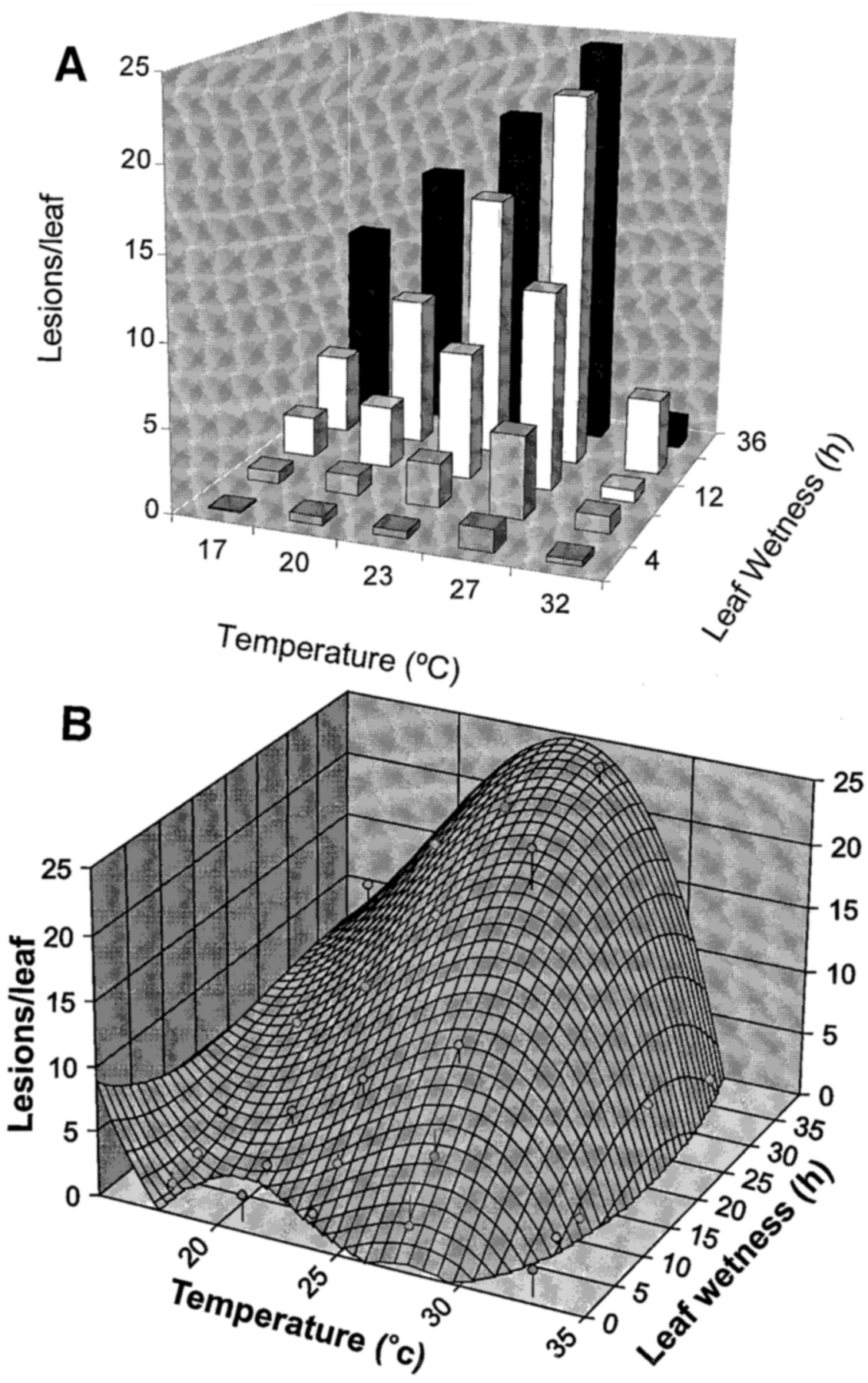

Fig. 1. Effect of temperature and time of leaf wetness on the number of lesions per leaf of Minneola tangelo inoculated with Alternaria sp. (A) Observed data, average of four experiments, (B) threedimensional representation providing the best fit for the data, $z=287.4-37.1 x-5.9 y+1.55 x^{2}+$ $0.05 y^{2}+0.49 x y-0.02 x^{3}-0.0003 y^{3}-0.0016 x y^{2}-0.009 x^{2} y$, where $x=$ temperature, $y=$ duration of leaf wetness, and $z=$ number of lesions per leaf. our preliminary studies, droplets of conidial suspensions were placed on the abaxial surfaces of young leaves, and the moisture was removed with filter paper at different times after inoculation. This technique proved excessively severe, and lesions developed even after brief wetting periods (T. L. Peever, unpublished). Subsequently, an in vitro spray inoculation technique was developed. Petioles of immature leaves were immersed into microcentrifuge tubes filled with water, and the tops of the tubes were wrapped with Parafilm to hold the leaves in place and to prevent evaporation of water. Tubes with leaves were placed in racks inside plastic chambers about $30 \times 23 \times 10 \mathrm{~cm}$ with water in the bottom to maintain $\mathrm{RH}$ near $100 \%$. Leaves were misted with the conidial suspension, and the chambers were covered and placed in incubators at various temperatures. After different periods of leaf wetness, six leaves were removed, dried with a fan, and incubated at room temperature $\left(21\right.$ to $24^{\circ} \mathrm{C}$ ) and $\mathrm{RH}$ (40 to $70 \%$ ). Thirty-six hours after completion of the experiment, the number of lesions on each leaf was counted.

Experiments. Four experiments were conducted with the SH-1 isolate to evaluate the effect of temperature and duration of leaf wetness on infection. In two experiments, the temperatures tested were 17 , $20,23,27$, and $32^{\circ} \mathrm{C}$, with leaf wetness durations of $4,8,12,24$, and $36 \mathrm{~h}$. In a third experiment, the same temperatures and leaf wetness durations were evaluated, except that the 36-h treatment was omitted. In the fourth experiment, temperatures tested were 23,27 , and $32^{\circ} \mathrm{C}$, with wetness durations of $4,8,12$, and 24 h. A $35^{\circ} \mathrm{C}$ temperature was included in two experiments, but no results are presented since heat damage to leaves precluded evaluation of pathogen effects. Noninoculated control leaves were included for each temperature and exposed to the longest duration of wetness used in each experiment.

Leaf lesion counts were square root transformed prior to analysis. Data were subjected to analysis of variance using an incomplete block design considering experiments as blocks using Minitab, Inc., programs (State College, PA). The ANOVA model was mixed, with time and temperature considered to be fixed factors and experiment a random factor. Data from the four experiments were pooled, and an equation and graph that fit the data were generated using the program Table Curve 3D (SPSS, Inc., Chicago, IL).

Two experiments were conducted to determine how different isolates responded to temperature and leaf wetness duration. Inoculum and leaves were produced, and inoculations were conducted as described above. Temperatures evaluated were 17 , 20,23 , and $27^{\circ} \mathrm{C}$, and durations of leaf wetness were 6,10 , and $24 \mathrm{~h}$. Forty-two leaves were inoculated with each isolate 
and maintained in separate humid chambers (one chamber for each temperature). Six leaves were removed and dried after each wetness period, and lesion counts were made about $36 \mathrm{~h}$ after completion of the experiment.

All isolates tested were recovered from Alternaria brown spot-affected Minneola tangelos in different citrus-producing areas of Florida. Two isolates, CPI (CPI-MIL25) and IMK (IMK-MIL-IS), were from groves near Immokalee in southwestern Florida. Isolate SH (SH-MIL-30S) was from a grove near Polk City, and isolate EV (EV-MIL-17S) was from a grove near Lake Alfred, both in central Florida. Isolates chosen represented the range of population diversity of Florida isolates based on analysis of randomly amplified polymorphic DNA (T. L. Peever, unpublished). Lesion counts were square root transformed prior to analysis. Data were subjected to analysis of variance to test the effects of isolate, temperature, and leaf wetness using experiments as blocks (Minitab). A mixed model was employed, with temperature and time as fixed factors and isolate and experiment as random factors.

\section{RESULTS}

Temperature and leaf wetness effects. The temperature and the time of leaf wetness significantly affected the amount of infection observed following inoculation (Table 1). Only low levels of infection were observed at $4 \mathrm{~h}$ of leaf wetness (Fig. 1A). With additional hours of leaf wetness, the amount of infection continued to increase up to $36 \mathrm{~h}$, the maximum period evaluated. The greatest amount of infection was observed at $27^{\circ} \mathrm{C}$ with all periods of leaf wetness. The number of lesions was progressively less at 23,20 , and $17^{\circ} \mathrm{C}$. Extended wetness periods were needed to achieve a high level of infection at $17^{\circ} \mathrm{C}$. At higher than optimum temperatures, infection decreased rapidly, with little infection at $32^{\circ} \mathrm{C}$ even with extended wetness periods. Experiment was also a significant factor in the analysis (Table 1). Experiments differed in the average number of lesions per leaf, but the trends were the same in all four experiments. No symptoms developed on controls.

The polynomial equation $z=287.4-$ $37.1 x-5.9 y+1.55 x^{2}+0.05 y^{2}+0.49 x y-$ $0.02 x^{3}-0.0003 y^{3}-0.0016 x y^{2}-0.009 x^{2} y$ provided a good fit for the observed data (adjusted $R^{2}=0.93$, Fig. 1B). Other more complex logistic and Gaussian equations provided equally good fits for the data, but calculations for predictions would be more difficult. The equation selected provided a good fit for the data over the range studied but would not apply for very low or high temperatures. Below $15^{\circ} \mathrm{C}$, values predicted increase again, and at temperatures much above $32^{\circ} \mathrm{C}$, values are zero or negative (Fig. 1B).
Isolate effects. In the two experiments where four isolates of $A$. alternata were evaluated (Figs. 2 and 3), temperature and leaf wetness duration were significant factors in the analysis (Table 2). The highest levels of infection occurred at 23 to $27^{\circ} \mathrm{C}$ with $24 \mathrm{~h}$ of leaf wetness. Isolate $\times$ temperature interaction was not significant; however, there was a significant isolate $x$ time of wetness interaction, indicating possible differences in aggressiveness of isolates with longer wetting periods.

There were no significant differences observed among isolates (Table 2), and the rankings of isolates were not consistent between experiments (Figs. 2 and 3). The IMK isolate produced high numbers of lesions under most conditions in experiment 1 , whereas the $\mathrm{SH}-1$ isolate produced the highest number in experiment 2 . The CPI isolate produced low numbers in both experiments, and the EV isolate produced moderate number of lesions in both experiments.

\section{DISCUSSION}

The optimum temperature for infection of Minneola tangelo leaves was about $27^{\circ} \mathrm{C}$. The optimum for most species of Alternaria is $25^{\circ} \mathrm{C}$ or above (10). Of course, optimum temperatures for pathogens of temperate crops, such as A. brassicae on oilseed rape (5), A. mali on apple (4), and Stemphylium vesicarium on pear (7) were closer to $20^{\circ} \mathrm{C}$. In the present study, the optimum length of the wetting period for A. alternata on citrus was at least $36 \mathrm{~h}$ and may possibly be longer. In most previous studies on other crops, $24 \mathrm{~h}$ was the maximum period evaluated and gave the highest level of infection $(5,7,10)$. However, Filajdic and Sutton (4) evaluated periods up to $48 \mathrm{~h}$ and found that maximum infection occurred at $36 \mathrm{~h}$ with $A$.
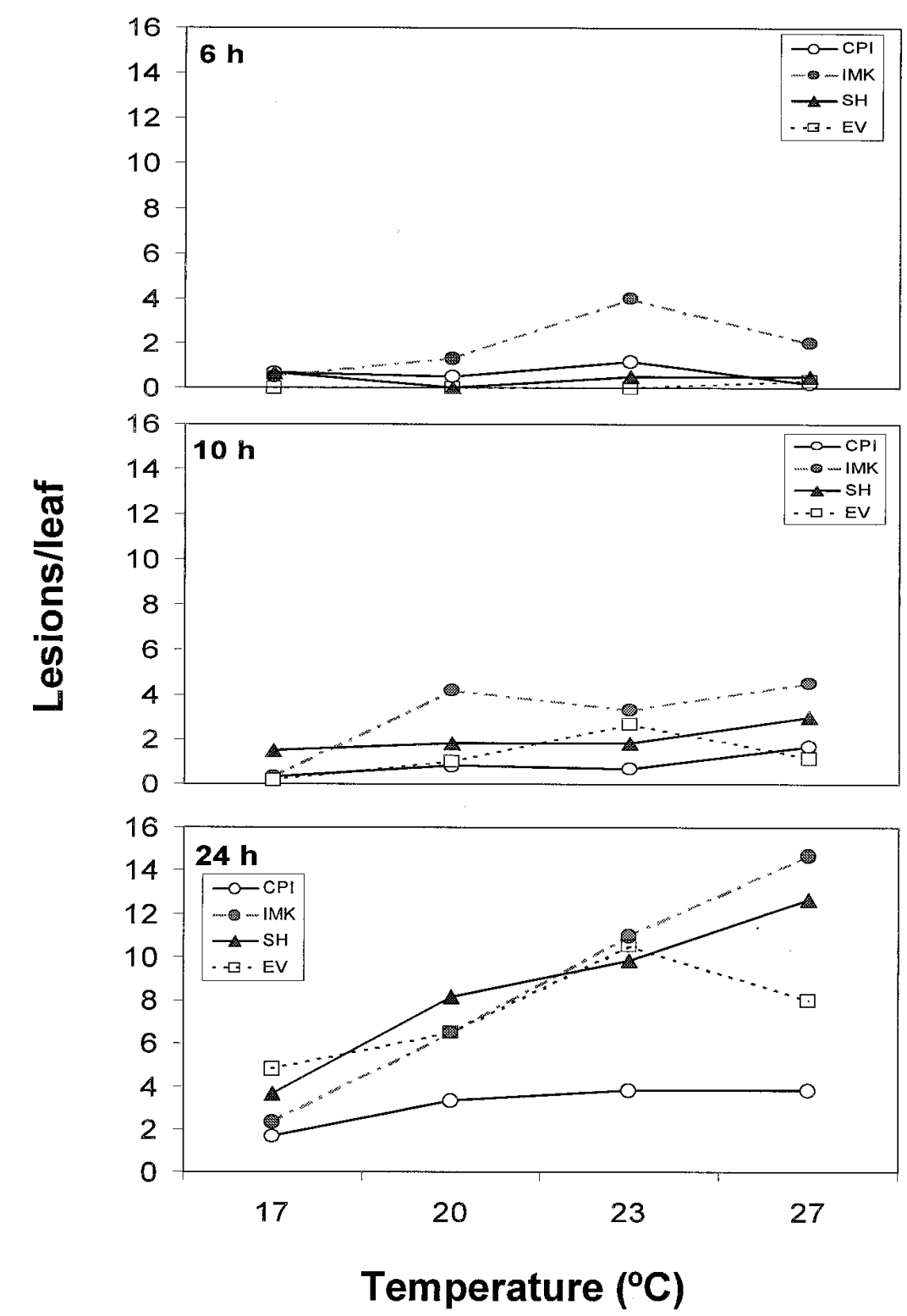

Fig. 2. Effect of isolate, temperature, and duration of leaf wetness on the number of lesions per leaf of Minneola tangelo inoculated with Alternaria sp. Experiment 1. 
mali. The optimum temperature and leaf wetness periods correspond well with our field data (15), indicating that much of the infection occurs during the summer rainy period in Florida when temperatures are near optimum for the fungus and extended periods of leaf wetness are common. The optimum temperature for lesion develop-
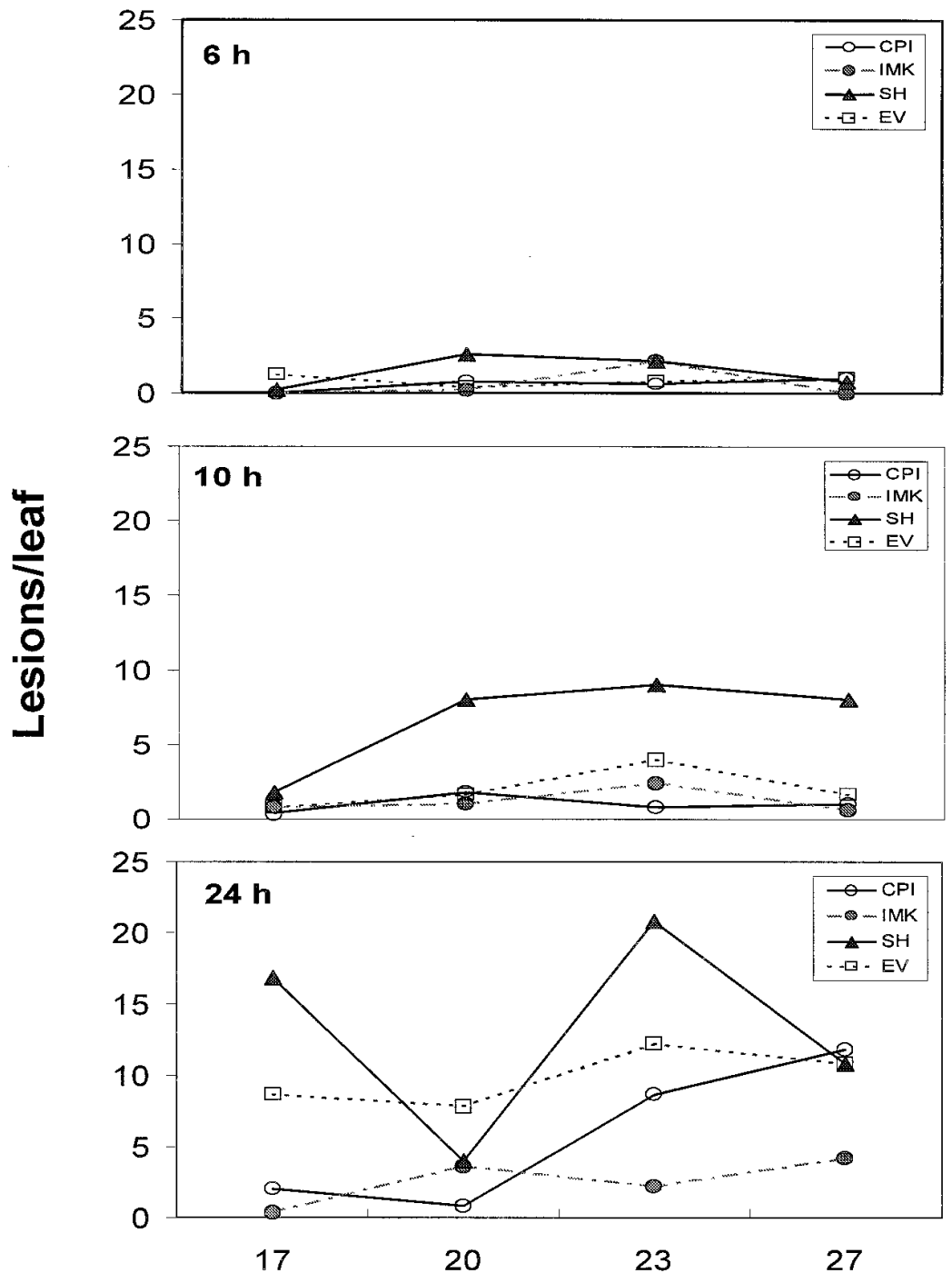

Temperature $\left({ }^{\circ} \mathrm{C}\right)$

Fig. 3. Effect of isolate, temperature, and duration of leaf wetness on the number of lesions per leaf of Minneola tangelo inoculated with Alternaria sp. Experiment 2.

Table 2. Analysis of variance of the effect of isolate, temperature, and duration of leaf wetness on the number of lesions per leaf of Minneola tangelo inoculated with different isolates of Alternaria sp.

\begin{tabular}{|c|c|c|c|c|c|c|c|}
\hline Source & df & SS & MS & EMS & $F$ test & $\boldsymbol{F}$ & $P$ \\
\hline Experiment & 1 & 0.22 & 0.22 & MSX & MSX/MSE & 0.5 & 0.470 \\
\hline Isolate & 3 & 7.71 & 2.57 & MSA & Approximate ${ }^{a}$ & 2.9 & 0.069 \\
\hline Temp & 3 & 9.81 & 3.27 & MSB & MSB/MSAB & 23.6 & $<0.0001$ \\
\hline Time & 2 & 52.46 & 26.23 & MSC & MSC/MSAC & 29.8 & 0.001 \\
\hline Isolate*temp & 9 & 1.25 & 0.14 & MSAB & MSAB/MSABC & 0.7 & 0.720 \\
\hline Isolate*time & 6 & 5.28 & 0.88 & MSAC & MSAC/MSABC & 4.3 & 0.007 \\
\hline Temp*time & 6 & 2.26 & 0.38 & MSBC & MSBC/MSABC & 1.8 & 0.147 \\
\hline $\begin{array}{l}\text { Isolate*temp* } \\
\text { time }\end{array}$ & 18 & 3.68 & 0.20 & MSABC & MSABC/MSE & 0.5 & 0.950 \\
\hline Error & 47 & 19.63 & 0.42 & MSE & & & \\
\hline Total & 95 & 102.31 & & & & & \\
\hline
\end{tabular}

${ }^{a}$ An exact $F$ test could not be obtained. The $F$ and $P$ values in the table were obtained from an approximate $F$ test for isolate using MSA/MSAC. This test is appropriate since isolate $\times$ temp interaction is not significant. A Satterthwaite approximate $F$ test $(8)$ yielded a similar result $(F=2.10, P=0.135)$.

ment for Alternaria brown spot in Israel was 22 to $25^{\circ} \mathrm{C}$, somewhat lower than observed with Florida isolates. These optima correspond well with the temperatures that occur during the major periods of reproduction of the pathogen in each location.

There were no significant differences observed among isolates used in this study, even though the isolates chosen were of maximum divergence genetically. This means that the model developed with these isolates should be generally applicable to the range of isolates found in Florida. Isolate response to temperature and wetness periods has not commonly been investigated. However, Filajdic and Sutton (4) attributed much of the variability in responses observed to differences in the aggressiveness of the isolates.

The descriptive model developed in this study has not yet been evaluated in the field. Fundamental models developed for similar diseases proved useful in predicting disease in field situations $(4,5,7,10)$. The major component missing from laboratorydeveloped models for field use is the amount of inoculum available. In many Minneola tangelo groves in Florida, disease is severe and infection can take place almost any time of the year that susceptible tissue is available (15). Thus, predictive models based solely on temperature and leaf wetness may prove useful in these situations. However, in some groves and at certain times of the year, inoculum may be the limiting factor because of prevailing environmental conditions. The equation yields unrealistic predictions below $15^{\circ} \mathrm{C}$ and above $32^{\circ} \mathrm{C}$. In field situations, this would not be a problem since temperatures are seldom below $15^{\circ} \mathrm{C}$ when susceptible tissue is available and would rarely exceed $32^{\circ} \mathrm{C}$ when moisture was present for infection.

Use of predictive models as a basis of fungicide applications for Alternaria brown spot control is complicated by the fact that disease develops so rapidly. Inoculated leaves that remained moist for $36 \mathrm{~h}$ often had already developed symptoms when they were removed from the chamber. Thus, there is no time to apply fungicides between an infection period and symptom development. Fungicide sprays, however, might be timed on the basis of cumulative daily severity values. Particularly in the spring in Florida, when extended dry periods may occur, risk advisories could allow growers to delay some fungicide sprays, resulting in fewer applications per year. Once the summer rainy season begins in June, regular sprays may be needed until the fruit become resistant in late July. In semiarid areas such as Israel and Turkey, where little or no rain occurs during the period of susceptibility $(12,13)$, infection is the result of prolonged periods of dew. With more variable temperatures and no rain, outbreaks of Alternaria brown spot may be more easily forecast. 


\section{ACKNOWLEDGMENTS}

We gratefully acknowledge the support of the Scientific and Technical Research Council of Turkey for the NATO Science Fellowship awarded to Y. Canihos. We appreciate the advice of Ramon Littell (Department of Statistics, University of Florida, Gainesville) and T. R. Gottwald (USDA, ARS, Orlando).

\section{LITERATURE CITED}

1. Canihos, Y., Erkilic, A., and Timmer, L. W. 1997. First report of Alternaria brown spot of Minneola tangelo in Turkey. Plant Dis. 81:1214.

2. Castro, B. L., Leguizamon, J. E., and Lopez, J. A. 1994. La mancha foliar de los citricos en la zona cafetera. Avances Técnicos No. 198. Cenicafe, Chinchiná, Caldas, Colombia.

3. Castro-Caicedo, B. L., and Montoya-Restrepo, E. C. 1996. Control químico de la mancha foliar del tangelo Minneola Alternaria tenuissima Avances Técnicos 234. Cenecafe, Chinchiná, Caldas, Colombia.

4. Filajdic, N., and Sutton, T. B. 1992. Influence of temperature and wetness duration on infection of apple leaves and virulence of different isolates of Alternaria mali. Phytopathology 82:1279-1283.

5. Hong, C. X., Fitt, B. D. L., and Welham, S. J. 1996. Effects of wetness period and temperature on development on dark spot (Alternaria brassicae) on oilseed rape (Brassica napus).
Plant Pathol. 45:1077-1089.

6. Kohmoto, K., Scheffer, R. P., and Whiteside, J. O. 1979. Host-selective toxins from Alternaria citri. Phytopathology 69:667-671.

7. Montesinos, E., Moragrega, C., Llorente, I., Vilardell, P., Bonaterra, A., Ponti, I., Bugiani, R., Cavanni, P., and Brunelli, A. 1995. Development and evaluation of an infection model for Stemphylium vesicarium on pear based on temperature and wetness duration. Phytopathology 85:586-592.

8. Neter, J., Wasserman, W., and Kutner, M. H. 1985. Applied Linear Statistical Models. 2nd ed. Irwin, Homewood, IL.

9. Pegg, K. G. 1966. Studies of a strain of Alternaria citri Pierce, the causal organism of brown spot of Emperor mandarin. Queensl. J. Agric. Anim. Sci. 23:14-18.

10. Rotem, J. 1994. The Genus Alternaria. Biology, Epidemiology, and Pathogenicity. American Phytopathological Society, St. Paul, MN.

11. Schutte, G. C., Lesar, K. H., Pelser, P. du T., and Swart, S. H. 1992. The use of tebuconazole for the control of Alternaria alternata on 'Minneola' tangelos and its potential to control post-harvest decay when applied as a preharvest spray. Proc. Int. Soc. Citric. 7:10701074.

12. Solel, Z. 1991. Alternaria brown spot on Minneola tangelos in Israel. Plant Pathol. 40:145-147.
13. Solel, Z., and Kimchi, M. 1997. Susceptibility and resistance of citrus genotypes to Alternaria alternata pv. citri. J. Phytopathol. 145:389-391.

14. Solel, Z., and Kimchi, M. 1998. Histopathology of infection of Minneola tangelo by Alternaria alternata pv. citri and the effect of host and environmental factors on lesion development. J. Phytopathol. 146:557561.

15. Solel, Z., Oren, Y., and Kimchi, M. 1997. Control of Alternaria brown spot of Minneola tangelo with fungicides. Crop Prot. 16:659664.

16. Timmer, L. W., Solel, Z., Gottwald, T. R., Ibañez, A. M., and Zitko, S. E. 1998. Environmental factors affecting production, release, and field populations of conidia of $\mathrm{Al}-$ ternaria alternata, the cause of brown spot of citrus. Phytopathology 88:1218-1223.

17. Whiteside, J. O. 1976. A newly recorded Alternaria-induced brown spot disease on Dancy tangerines in Florida. Plant Dis. Rep. 60:326-329.

18. Whiteside J. O. 1979. Alternaria brown spot of Dancy tangerines and its control. Proc. Fla. State Hortic. Soc. 92:34-37.

19. Whiteside, J. O. 1988. Alternaria brown spot of mandarins. Page 8 in: Compendium of Citrus Diseases. J. O. Whiteside, S. M. Garnsey, and L. W. Timmer, ed. American Phytopathological Society, St. Paul, MN. 